incentives offered to them, as well as by public opinion and by the availability of services, both public and private, which would make it easier for married women to go out to work while successfully dealing with their domestic responsibilities. Authorities, too, will have their part to play, by helping to provide such services, by amending the existing factory legislation, and in various other ways.

The onus of carrying out adjustments necessary for absorbing into the labour market employees whose major responsibilities lie outside their field of employment cannot be put on employers alone. Novertheless, their attitudes towards married women workers and the experiences they have gained with them under present conditions of employment will be of great importance in formulating future policies. The survey indicates that married women workers are considered to have disadvantages and that many employers will not willingly engage them if alternative labour is available. Other employers, while prepared to accept married women for unskilled jobs, will not readily provide them with skilled work or offer them opportunities for promotion.

In the majority of firms employing more than 500 workers, managements maintain that the attendance record of married women is inferior to that of men, yet this is not true of firms employing less than that number. If this were correct, it might well mean that something can be learned about working conditions conducive to improving the attendance record of married women employees. The survey confirms that the majority of married women in employment are over the age of thirty-five, and that this holds true for part-time workers to an even larger extent than for full-time employees. The reluctance of many firms to provide married women with skilled work or opportunities for promotion suggests that prejudice against this kind of labour is preventing its effective utilization.

From the community's point of view, women are of great importance both as workers and as wives and mothers, and it would seem necessary to provide them with facilities to perform both these functions simultaneously and effectively so that noither their homes nor their jobs suffer unduly from this duality of jobs. Some firms are prepared to do this, but the majority, while giving consideration to all employees with domestic or personal difficulties, are not prepared to single out married women for special consideration. Those firms which make special provisions for married women are often forced to do this in order to attract and retain this class of labour in areas where it is in short supply. If firms are to meet their demands on labour in the future it would seem that more and more will have to rovise their egalitarian policies and be prepared to make concessions.

Some firms are not prepared to offer married women such favourable conditions of service as their other employees. For example, if there is redundancy the tendency is for married women to become dismissed first; they may be excluded from the superannuation scheme or, if they are included, entry is limited to those who can fulfil particular criteria not applied to other employees. Part-time married women workers, although generally employed, are not popular, mainly bocause of their irregularity of attendance and high labour turnover. Firms find them useful, however, for evening or seasonal work and on clerical jobs.

The general conclusion is that it will need a longer period of full employment and industrial expansion before employers can be persuaded to regard married women as a substantial and useful part of their normal personnel, for whom suitable working conditions will have to be created.

\title{
PUBLIC HEALTH AND HOUSING
}

\begin{abstract}
THE World Health Organization recently convened a meeting of experts to discuss the improvement of housing and the promotion of urban and rural development. The report of the Committee* identifies housing as a complex process involving many different disciplines, and should be of interest not only to public health officers and sanitary engineers, but also to town and country planners, architects, building engineers, sociologists and many others whose services are needed in the task of improving living conditions.

After a brief general review of the subject, which includes a discussion of housing standards, the rolationship between housing and hoalth, and world housing conditions, the report examines the criteria for a healthful residential environment, including: design and layout of individual dwellings; water supply and sewage disposal systems; domestic facilities; physiological requirements affected by such environmental factors as temperature humidity, ventilation and illumination; protection from fire and other hazards; community planning.
\end{abstract}

* World Health Organization. Technical Report Series. No. 225: Expert Committee on the Public Health Aspects of Housing-First Report. Pp. 60, (Geneva: World Health Organization; London:
H.M.S.o., 1961.) 2 Sw'ss francs; 38. 6d.
Over the years, the housing shortage in cities has sometimes led to a neglect of the countryside. Often rural housing may be so defective that the population is induced to move to the towns in search of habita. tions which, although often overcrowded and in slum areas, are preferable to the sub-standard rural dwelling formerly occupied. The report notes the problems peculiar to rural housing and suggests some of the ways in which they can be overcome. Another topic dealt with is housing for the elderly and the handicapped, and, in particular, the services and facilities needed to meet the physiological and psychological requirements of these special groups.

The Committee also examined the obligations of public health agoncies in the provision of safe and sanitary housing, and their legal functions in protection of the residential environment. The part that public health workers can play as community developers is underlined, and the training of these and other technical personnel in the field of housing and community planning is discussed. Finally, the report enumerates some of the areas in which research is needed and makes suggestions for future action, such as the formation of national committees for housing and health and for the establishment of housing programmes within the central health agencies. 